\title{
Differentiation of wines made from berry and drupe fruits according to their phenolic profiles
}

\author{
U. Čakar ${ }^{1}$, A. Petrović ${ }^{2}$, M. Jankovićs ${ }^{3}$ B. Pejin ${ }^{4}$, V. Vajs ${ }^{5}$, M. Čakar ${ }^{1}$ and B. Djordjević ${ }^{1}$ \\ ${ }^{1}$ Faculty of Pharmacy, University of Belgrade, Belgrade, Serbia \\ ${ }^{2}$ Faculty of Agriculture, University of Belgrade, Belgrade-Zemun, Serbia \\ ${ }^{3}$ Faculty of Chemistry, University of Belgrade, Belgrade, Serbia \\ ${ }^{4}$ Institute for Multidisciplinary Research - IMSI, University of Belgrade, Belgrade, Serbia \\ ${ }^{5}$ Institute of Chemistry, Technology and Metallurgy, University of Belgrade, Belgrade, Serbia
}

\section{Summary}

Introduction - Fruit and their products, including fruit wines, represent a rich source of natural bioactive compounds. This study focusing on fruit wines (prepared from commercially grown fruits by Serbian producers) has included the investigation of their chemical composition and biological activity. Materials and methods - Black chokeberry, blueberry, raspberry, blackberry and cherry were used for wine production by innovative vinification procedure, with or without using sugar and enzymatic preparation glycosidase, respectively. Selected phenolics were identified and quantified by UPLC/MS-MS analysis, while Total Phenolic Content (TPC) was determined by the Folin-Ciocalteu method. In addition to this, 2,2-diphenyl-1-picrylhydrazyl (DPPH) and FRAP (Ferric Reducing Ability of Plasma) methods were applied for the preliminary evaluation of anti-DPPH radical activity and redox potential respectively at in vitro conditions. Results and discussion - Among the fruit wines examined within this study, the blackberry one stood out for profound FRAP (115.23 $\left.\mathrm{mmol} \mathrm{L}^{-1} \mathrm{Fe}^{2+}\right)$, DPPH (1.11\%) and TPC values $\left(2,395 \mathrm{mg} \mathrm{GAE}^{-1}\right)$. On the other hand, the raspberry wine showed the lowest potential towards the aforementioned parameters. Using principal component analysis, these fruit wines were chemically differentiated, according to the predominant phenolic compounds. Conclusions - All fruit wine samples displayed a good antioxidant potential with the blackberry one being most potent. Such a finding is of particular importance for Serbia as one of the leading producers of this edible fruit both in Europe and rest of the world.

Keywords

bioactivity, blackberry, chemical composition, FRAP, vinification

\section{Introduction}

Regular consumption of 5 to 7 portions of fresh fruit and vegetables, as well as two glasses of red wine a day, may positively affect human health (German, 1997). Antioxidant compounds are partially responsible for food health-promoting effects, since they may prevent development of a broad range of diseases and disorders including heart disease and cancer (Dufresne and Farnworth, 2001).

\section{Significance of this study}

What is already known on this subject?

- Fruit antioxidants are well known for their healthpromoting properties.

What are the new findings?

- Blackberry fruit wines produced by innovative vinification procedure (partially based on sugar addition due to ethanol increasing) possessed a high content of phenolic compounds.

What is the expected impact on horticulture?

- The findings presented herein primarily may inspire the production of blackberry fruit wines (by vinification procedure encompassing use of both sugar and enzymatic preparation glucosidase) with a profound antioxidant potential.

Antioxidant potential of fruits and their products derives from numerous naturally occurring compounds including phenolic acids, flavonoids and anthocyanins (Cao et al., 1997; Wang, 2003). For example, fruits are considered as a good source of hydroxycinnamic acids, first of all, caffeic, ferulic, $p$-coumaric, sinapinic and chlorogenic acids (Meyer et al., 1998). In some cases, chlorogenic acid may be the most abundant phenolic (Robards et al., 1999). Hydroxybenzoic acid derivatives such as $p$-hydroxybenzoic, protocatechuic, vanillic and syringic acids are also present (Torres et al., 1987). It is worth mentioning that during fruit processing these compounds retain in the final product (Czyzowska and Pogorzelski, 2002).

Berry-fruit wines are known for their good scavenging activity of free radicals (Heinonen et al., 1998; Pinhero and Paliyath, 2001). Additionally, phenolics from blueberries have potential in the management of non-communicable diseases (Stull et al., 2010; Johnson et al., 2011), while cherry wine displays a potent antioxidant potential (Yoo et al., 2010). Similarly, grape wine, riched with phenolic compounds, also exhibits promising antioxidant potential (Protić et al., 2015; Đorđević et al., 2017a).

Till to date Europe has been well recognised for the production of blackberries. In addition to this, Serbia is ranked first among its European producers. Indeed, such a trend has well contributed to the development of Serbian fruit wine production during last two decades (Strik et al., 2007; FAO, 2012). 
Unlike majority of previous studies in the field, this one has included several fruit kinds (Amidžić Klarić et al., 2011; Pantelić et al., 2014). Indeed, the focus has been on the pilot wine samples (not commercial ones) produced by innovative vinification procedure, i.e., with or without using sugar and enzymatic preparation glycosidase (EPG), respectively. Sugar and enzyme were added to the fruit must due to the investigation of their influence both on the content of phenolic compounds and antioxidant potential of the selected fruit wine samples. The overall aim was to differentiate fruit wines according to the phenolic profiles.

\section{Materials and methods}

\section{Plant material}

The fruits were purchased from commercial producers during 2014 (phytosanitary health, 100\%): blackberry (Rubus sp.) cultivar Čačanska bestrna was from Bojnik, Serbia; raspberry (Rubus idaeus) cultivar Meeker from Valjevo, Serbia; black chokeberry (Aronia melanocarpa Heynh.) and blueberry (Vaccinium myrtilus) were from the region of Rudnik mountain, Serbia; sour cherry (Prunus cerasus L.) cultivar Sumadinka was from the region of Grocka, Serbia.

\section{Wine making}

The experiments were divided in two sets. In both cases, fruit was firstly disintegrated. Subsequently, $10 \mathrm{~g}$ of $\mathrm{K}_{2} \mathrm{~S}_{2} \mathrm{O}_{5} 100 \mathrm{~kg}^{-1}$ was added to the obtained pomace. The first set included the control without added sugar. Total soluble solids (expressed in ${ }^{\circ}$ Brix) were measured in the fruit pomace of the first set. Aiming to increase total soluble solids of must up to $20.5^{\circ}$ Brix, sugar was added in the second set. Within the aforementioned sets of the experiment, two subsets were performed. While the first sub-set included addition of $2 \mathrm{~g}$ of enzymatic preparation glycosidase (EPG $100 \mathrm{~g}^{-1}$; Enartis, Italy), the second one omitted its use. Both sub-sets were inoculated with pure culture of the selected commercial wine yeasts (ICV D254, Lallemand, Canada, and Lievito Secco, Enartis, Italy) in the amount of $20 \mathrm{~g} 100 \mathrm{~kg}^{-1}$, respectively. Both yeasts, that represent a Saccharomyces cerevisiae strain, have been previously used in the vinification of grape and fruit wines in Serbia. Stone fruit (sour cherry) was processed in the same way. Actually, there were two sets of pomace fermentation, with and without pit. The set with pit was expected to be enriched with phenolics due to ethanol extraction during fermentation in vinification barrels with pigeage system (Hromil, Kovilj-Serbia). More precisely, $25 \mathrm{~kg}$ of fruit was fermented in the barrels of $30 \mathrm{~L}$. Alcohol fermentation was conducted at $20^{\circ} \mathrm{C}$ over 7 to 10 days. During this process, the pomace was stirred twice a day. After fermentation, each fruit wine was separated from the pomace by sedimentation. Afterwards, they were racked off the lees and kept at $12^{\circ} \mathrm{C}$ for the next six months, until further studies.

\section{Physicochemical properties of fruit wines}

$\mathrm{pH}$ value was determined by a microprocessor-based $\mathrm{pH} / \mathrm{mV} /{ }^{\circ} \mathrm{C} \mathrm{pH} 212$ (Hanna Instruments, Woonsocket, RI, USA). Further, $25 \mathrm{~mL}$ was titrated with $0.25 \mathrm{M} \mathrm{NaOH}$ aiming to estimate Total Titratable Acidity (TTA) of the fruit wine samples. The titration endpoint $(\mathrm{pH} 7.0 \pm 0.5)$ was indicated by $\mathrm{pH}$ meter. Total Soluble Solids (TSS, expressed in ${ }^{\circ} \mathrm{Brix}$ ) were measured in the fruit juice using the refractometer PAL-87S (Atago, Tokyo, Japan). The alcohol concentration was determined by the alcohol density meter DMA 35 (Anton Paar, Graz, Austria) after samples distillation. The strength by volume (vol. \%) was calculated using $20^{\circ} \mathrm{C} / 20^{\circ} \mathrm{C}$ tables (OIV, 2009).

\section{Standards and reagents}

All chemicals and reagents of analytical grade were purchased from Sigma Aldrich (Steinheim, Germany). The Premium Syringe Filters (Captiva) Regenerated Cellulose $(0.45 \mu \mathrm{m}, 15 \mathrm{~mm})$ were obtained from Agilent Technologies (Santa Clara, CA, USA). Water HPLC grade was provided by Ultrapure Water System Arium pro UV Sartorius (Göttingen, Germany).

\section{Solid Phase Extraction (SPE)}

Aiming to decrease the influence of the matrix during phenolics identification, solid-phase extraction (SPE) was applied, Oasis HLB 6CC 200 mg cartridges (Waters, Milford, MA, USA) (Kaihkonen et al., 2001). While the fruit wine samples were filtered through syringe filter, SPE was performed as described by Ferreiro-González et al. (2014), with some modification. The conditioning of cartridges and equilibration were carried out with $5 \mathrm{~mL}$ of methanol and HPLC-grade water, respectively. Furthermore, $5 \mathrm{~mL}$ of each sample was loaded. The washing was conducted both with $5 \mathrm{~mL}$ of HPLCgrade water and $5 \%$ methanol. The eluation was carried out with $6 \times 1 \mathrm{~mL}$ of methanol containing $0.1 \%$ formic acid. Finally, each sample was evaporated to dryness, reconstituted in $1 \mathrm{~mL}$ of solution like gradient at the start and used for the analysis.

\section{UPLC/MS-MS analysis}

UPLC/MS-MS analysis was performed using a Waters Acquity Ultra Performance H-Class System (Waters, Milford, MA, USA). UPLC separation was achieved on the Acquity UPLC BEH $\mathrm{C}_{18}$ column $(1.7 \mu \mathrm{m}, 150 \mathrm{~mm} \times 2.1 \mathrm{~mm}$ i.d. $)$. During analysis, the column was kept at $40^{\circ} \mathrm{C}$, while the flowrate and injection volume were $0.4 \mathrm{~mL} \mathrm{~min}^{-1}$ and $1.0 \mu \mathrm{L}$, respectively. The mobile phase consisted of $0.2 \%$ formic acid in water (solvent A) and acetonitrile (solvent B). The following gradient was used: $0-0.5 \mathrm{~min} 95 \%$ solvent $\mathrm{A} ; 0.5-8.0$ min $50 \%$ solvent A (linear change in the composition of the mobile phase); 8.0-10.0 min 95\% solvent A. Phenolic compounds were identified by comparing their retention times $\left(t_{R}\right)$ and mass spectra with the relevant standards. IntelliStart program (Waters, Milford, MA, USA; 2005) provided parameters that were used for quantification (Table 1). UPLC was coupled with a triple quadrupole mass spectrometer Acquity TQD (Waters, Milford, MA, USA) with the software MassLynx 4.1 (Waters, Milford, MA, USA; 2005). Finally, the ionisation source conditions were as followed: capillary voltage of $4 \mathrm{kV}$, source temperature of $150^{\circ} \mathrm{C}$ and desolvation temperature of $450^{\circ} \mathrm{C}$, with a flow rate of $650 \mathrm{~L} \mathrm{~h}^{-1}$. Nitrogen and argon were used as cone and collision gases, respectively.

\section{Ferric Reducing Ability of Plasma (FRAP) test}

Redox potential of the fruit wine samples was determined using the Ferric Reducing Ability of Plasma (FRAP) test (Benzie and Strain, 1996). The obtained results were expressed in $\mathrm{mmol} \mathrm{L}^{-1} \mathrm{Fe}^{2+}$.

\section{2,2-diphenyl-1-picrylhydrazyl (DPPH)}

Anti-DPPH radical activity of the fruit wine samples was evaluated as previously described (Blois, 1958). The obtained results were expressed as a reciprocal value I (\%) multiplied by 100 . 
TABLE 1. The conditions for identification and quantification of phenolic compounds.

\begin{tabular}{lccccccc}
\hline Phenolic compound & $\begin{array}{c}\text { Molecular } \\
\text { formula }\end{array}$ & Mass & $\begin{array}{c}\text { lonisation } \\
\text { mode } \\
\text { ESI }\end{array}$ & $\begin{array}{c}\text { MRM } \\
\text { transition }\end{array}$ & $\begin{array}{c}\text { Cone } \\
\text { voltage } \\
(\mathrm{V})\end{array}$ & $\begin{array}{c}\text { Collision } \\
\text { energy } \\
(\mathrm{eV})\end{array}$ & $\begin{array}{c}\mathrm{t}_{R} \\
(\mathrm{~min})\end{array}$ \\
\hline Epicatechin & $\mathrm{C}_{15} \mathrm{H}_{14} \mathrm{O}_{6}$ & 290 & + & $291 \rightarrow 139$ & 26 & 16 & 4.49 \\
Sinapinic acid & $\mathrm{C}_{11} \mathrm{H}_{12} \mathrm{O}_{5}$ & 224 & + & $225 \rightarrow 175$ & 12 & 14 & 5.47 \\
Gallic acid & $\mathrm{C}_{7} \mathrm{H}_{6} \mathrm{O}_{5}$ & 170 & - & $169 \rightarrow 125$ & 30 & 20 & 1.68 \\
Protocatechuic acid & $\mathrm{C}_{7} \mathrm{H}_{6} \mathrm{O}_{4}$ & 154 & - & $153 \rightarrow 109$ & 30 & 20 & 2.94 \\
p-Hydroxybenzoic acid & $\mathrm{C}_{7} \mathrm{H}_{6} \mathrm{O}_{3}$ & 138 & - & $137 \rightarrow 93$ & 30 & 20 & 3.85 \\
Catechin & $\mathrm{C}_{15} \mathrm{H}_{14} \mathrm{O}_{6}$ & 290 & + & $291 \rightarrow 139$ & 26 & 20 & 3.96 \\
Chlorogenic acid & $\mathrm{C}_{16} \mathrm{H}_{18} \mathrm{O}_{9}$ & 354 & + & $355 \rightarrow 163$ & 20 & 12 & 3.93 \\
Vanillic acid & $\mathrm{C}_{8} \mathrm{H}_{8} \mathrm{O}_{4}$ & 168 & + & $169 \rightarrow 93$ & 26 & 14 & 4.34 \\
Caffeic acid & $\mathrm{C}_{9} \mathrm{H}_{8} \mathrm{O}_{4}$ & 180 & - & $179 \rightarrow 135$ & 30 & 20 & 4.27 \\
p-Coumaric acid & $\mathrm{C}_{9} \mathrm{H}_{8} \mathrm{O}_{3}$ & 164 & - & $163 \rightarrow 119$ & 22 & 22 & 5.07 \\
Ellagic acid & $\mathrm{C}_{14} \mathrm{H}_{6} \mathrm{O}_{8}$ & 302 & - & $301 \rightarrow 163$ & 50 & 56 & 7.06 \\
\hline
\end{tabular}

ESI - Electrospray lonisation; MRM - Multiple Reaction Monitoring; $t_{R}$ - Retention time.

\section{Total Phenolic Content (TPC)}

Total Phenolic Content (TPC) of the fruit wine samples was estimated by the Folin-Ciocalteu (FC) method using gallic acid as a standard (Woraratphoka et al., 2007). The results were expressed in $\mathrm{mg} \mathrm{L}^{-1}$ of gallic acid equivalents (mg GAE $L^{-1}$ ).

\section{Total FRAP corrected}

Dilutions with free $\mathrm{SO}_{2}$ concentrations from 10 to $25 \mathrm{mg}$ $\mathrm{L}^{-1}$ were prepared (initial solution: $0.075 \mathrm{~g}$ tartaric acid in $1 \mathrm{~L}$ distilled water). $\mathrm{pH}$ value 3.26 was the average one for the analysed samples. The concentration of free $\mathrm{SO}_{2}$ (ranging from 10 to $25 \mathrm{mg} \mathrm{L}^{-1}$ ) was adjusted by $\mathrm{K}_{2} \mathrm{~S}_{2} \mathrm{O}_{5}$ addition. Iodometric titration according to Ripper was used for estimation of free $\mathrm{SO}_{2}$ concentrations (Tanner and Brunner, 1979). The absorbance was recorded at $593 \mathrm{~nm}$. Corrected FRAP value $\left(\mathrm{FRAP}_{\text {corrected }}\right)$ was obtained from difference between FRAP value of the fruit wine sample with free $\mathrm{SO}_{2}\left(\mathrm{FRAP}_{\text {total }}\right)$ and model solution value with the same $\mathrm{SO}_{2}$ content $\left(\mathrm{FRAP}_{\text {model }}\right.$ solution) (Figure 1).

\section{Statistical analysis}

Statistical analysis was conducted by using the software SPSS Statistic V22.0 (IBM, Chicago, IL, USA; 2014); $t$-test for the paired samples; two-way ANOVA, with Tukey post hoc test for subgroup differences; and Principal Component Analysis (PCA). Linear regression correlation analysis was obtained by Origin Pro 8 (OriginLab, Northampton, MA, USA; 2008) (Figure 1).

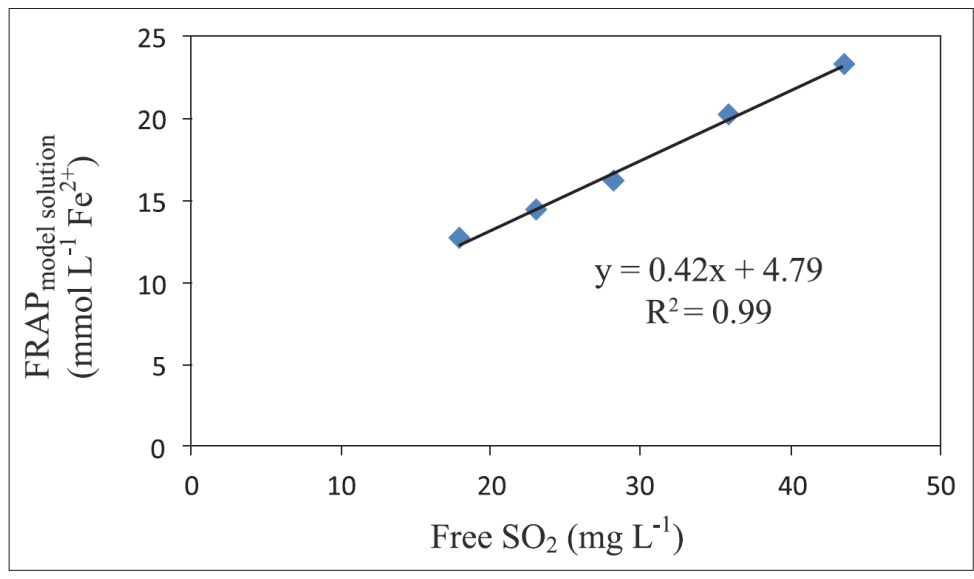

\section{Results and discussion}

Physicochemical properties were determined in all fruit wine samples (Table 2, Supplementary material). TSS content in must enables prediction of alcohol content (Vol. \%) in the wine. On the other hand, wine's pH directly affects its flavour and aroma.

\section{UPLC/MS-MS analysis}

The relevant fruit wine samples prepared without sugar and EPG were compared with those ones made with sugar and/or EPG (Table 3). Actually, the sugar content significantly affected the content of selected phenolic compounds $(p<0.05)$. Higher sugar content before fermentation leads to more abundant alcohol content in the final product (Table 2 , Supplementary material). Compared with grape, the fruit juices are usually lower in sugar and higher in acids (Swa$\mathrm{mi}$ et al., 2014). EPG liberates phenolics from the glycoside form. This is supported by Eder et al. (2000) who reported that EPG increased the content of resveratrol free isomers in grape wines. Different wine cultivars and winemaking techniques significantly affected the phenolic content in the grape wine (Atanacković et al., 2012). The optimal conditions for the production of red wines enriched with phenolics may also be applied to the fruit wines. Grape wine represents a good source of phenolics such as epicatechin, catechin and phenolic acids, the compounds that are also abundant in the fruit wines (Đorđević et al., 2017b). In essence, grape wine technology is similar to those of the fruit wine (Joshi, 2009).

FIGURE 1. Linear correlation between free $\mathrm{SO}_{2}$ and FRAP ${ }_{\text {model solution }}$. 
TABLE 2. Physico-chemical characterisation of the fruit wine samples.

\begin{tabular}{|c|c|c|c|c|c|c|c|c|c|}
\hline \multirow[b]{2}{*}{ Type of fruit } & \multirow[b]{2}{*}{$\begin{array}{c}\text { Type of } \\
\text { vinification }\end{array}$} & \multicolumn{4}{|c|}{ Lievito Secco yeast } & \multicolumn{4}{|c|}{ ICV D254 yeast } \\
\hline & & $\begin{array}{c}\text { Total soluble } \\
\text { solids must } \\
\left({ }^{\circ} \text { Brix }\right)\end{array}$ & $\mathrm{pH}$ & $\begin{array}{c}\text { Total titratable } \\
\text { acid } \\
\text { (malic acid } \\
\mathrm{g} \mathrm{L}^{-1} \text { ) }\end{array}$ & $\begin{array}{l}\text { Alcohol } \\
\text { content } \\
\text { (Vol. \%) }\end{array}$ & $\begin{array}{c}\text { Total soluble } \\
\text { solids must } \\
\text { ('Brix) }\end{array}$ & $\mathrm{pH}$ & $\begin{array}{c}\text { Total titratable } \\
\text { acid } \\
\text { (malic acid } \\
\mathrm{g} \mathrm{L}^{-1} \text { ) }\end{array}$ & $\begin{array}{l}\text { Alcohol } \\
\text { content } \\
\text { (Vol. \%) }\end{array}$ \\
\hline $\begin{array}{l}\text { Black } \\
\text { chokeberry }\end{array}$ & control & 11.50 & 3.60 & 10.00 & 6.61 & 11.94 & 3.55 & 9.32 & 6.87 \\
\hline $\begin{array}{l}\text { Black } \\
\text { chokeberry }\end{array}$ & $\begin{array}{l}\text { + sugar } \\
\text { - enzyme }\end{array}$ & 18.54 & 3.66 & 10.70 & 10.92 & 18.66 & 3.45 & 9.32 & 11.02 \\
\hline $\begin{array}{l}\text { Black } \\
\text { chokeberry }\end{array}$ & $\begin{array}{l}\text { - sugar } \\
+ \text { enzyme }\end{array}$ & 11.69 & 3.61 & 10.35 & 6.73 & 12.07 & 3.53 & 8.97 & 6.95 \\
\hline $\begin{array}{l}\text { Black } \\
\text { chokeberry }\end{array}$ & $\begin{array}{l}\text { + sugar } \\
+ \text { enzyme }\end{array}$ & 18.83 & 3.65 & 9.32 & 11.11 & 19.10 & 3.57 & 9.66 & 11.23 \\
\hline Blueberry & control & 14.21 & 2.86 & 6.76 & 8.27 & 14.54 & 2.94 & 6.55 & 8.45 \\
\hline Blueberry & $\begin{array}{l}\text { + sugar } \\
\text { - enzyme }\end{array}$ & 18.31 & 2.85 & 7.94 & 10.8 & 18.90 & 2.91 & 7.18 & 11.15 \\
\hline Blueberry & $\begin{array}{l}\text { - sugar } \\
+ \text { enzyme }\end{array}$ & 14.54 & 2.86 & 7.25 & 8.45 & 14.66 & 2.90 & 8.28 & 8.57 \\
\hline Blueberry & $\begin{array}{l}\text { + sugar } \\
+ \text { enzyme }\end{array}$ & 18.64 & 2.91 & 7.73 & 10.95 & 19.21 & 2.84 & 7.59 & 11.31 \\
\hline Blackberry & control & 13.37 & 2.81 & 8.28 & 7.77 & 13.66 & 2.81 & 6.76 & 7.93 \\
\hline Blackberry & $\begin{array}{l}\text { + sugar } \\
\text { - enzyme }\end{array}$ & 17.20 & 2.90 & 7.45 & 10.11 & 17.40 & 2.86 & 6.62 & 10.20 \\
\hline Blackberry & $\begin{array}{l}\text { - sugar } \\
+ \text { enzyme }\end{array}$ & 13.58 & 2.83 & 8.14 & 7.88 & 13.83 & 2.76 & 6.42 & 8.03 \\
\hline Blackberry & $\begin{array}{l}\text { + sugar } \\
+ \text { enzyme }\end{array}$ & 17.57 & 2.91 & 9.32 & 10.31 & 17.70 & 2.90 & 6.76 & 10.43 \\
\hline Raspberry & control & 12.83 & 3.26 & 13.46 & 7.41 & 12.61 & 3.12 & 13.11 & 7.27 \\
\hline Raspberry & $\begin{array}{l}\text { + sugar } \\
\text { - enzyme }\end{array}$ & 16.11 & 3.15 & 13.80 & 9.41 & 15.89 & 3.08 & 12.08 & 9.28 \\
\hline Raspberry & $\begin{array}{l}\text { - sugar } \\
\text { + enzyme }\end{array}$ & 13.18 & 3.30 & 12.77 & 7.63 & 12.88 & 3.20 & 10.90 & 7.45 \\
\hline Raspberry & $\begin{array}{l}\text { + sugar } \\
+ \text { enzyme }\end{array}$ & 16.72 & 3.00 & 13.46 & 9.81 & 16.53 & 2.98 & 10.00 & 9.67 \\
\hline Sour cherry & $\begin{array}{l}\text { control } \\
\text { - pit }\end{array}$ & 12.04 & 3.43 & 6.90 & 6.93 & 11.82 & 3.80 & 5.60 & 6.79 \\
\hline Sour cherry & $\begin{array}{c}\text { + sugar } \\
\text { - enzyme/- } \\
\text { pit }\end{array}$ & 17.96 & 3.34 & 8.14 & 10.54 & 17.79 & 3.53 & 8.69 & 10.44 \\
\hline Sour cherry & $\begin{array}{l}\text { - sugar } \\
+ \text { enzyme/- } \\
\text { pit }\end{array}$ & 12.32 & 3.20 & 8.63 & 7.12 & 12.18 & 3.37 & 8.90 & 7.01 \\
\hline Sour cherry & $\begin{array}{l}+ \text { sugar } \\
+\underset{\text { pit }}{\text { enzyme/- }} \\
\text { pit }\end{array}$ & 18.44 & 3.34 & 7.25 & 10.85 & 18.17 & 3.31 & 8.63 & 10.67 \\
\hline Sour cherry & $\begin{array}{l}\text { control } \\
+ \text { pit }\end{array}$ & 12.61 & 3.45 & 6.90 & 7.27 & 12.43 & 3.46 & 7.80 & 7.18 \\
\hline Sour cherry & $\begin{array}{c}\text { + sugar } \\
\text { - enzyme/+pit }\end{array}$ & 18.58 & 3.44 & 7.94 & 10.92 & 18.42 & 3.33 & 6.55 & 10.85 \\
\hline Sour cherry & $\begin{array}{c}\text { - sugar } \\
\text { +enzyme/+pit }\end{array}$ & 12.92 & 3.45 & 6.90 & 7.48 & 12.64 & 3.29 & 7.04 & 7.31 \\
\hline Sour cherry & $\begin{array}{c}\text { +sugar } \\
\text { +enzyme/+pit }\end{array}$ & 18.95 & 3.55 & 7.94 & 11.18 & 18.81 & 3.59 & 6.55 & 11.06 \\
\hline
\end{tabular}

Abbreviations: control - without sugar and enzymatic preparation glycosidase; + sugar - with sugar; - sugar - without sugar; + enzyme - with enzyme; - enzyme -without enzyme; + pit - with pit; - pit - without pit. 


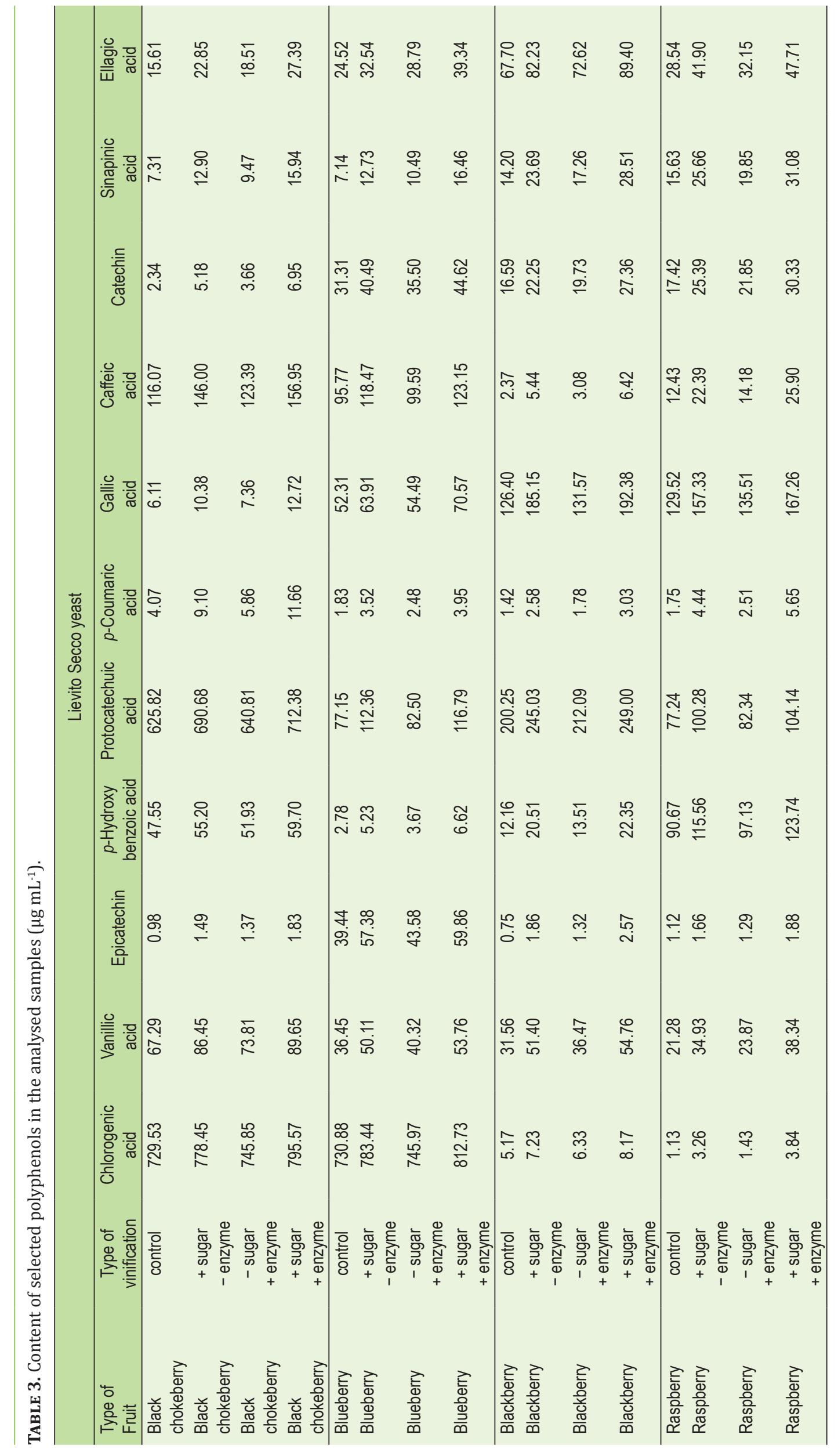




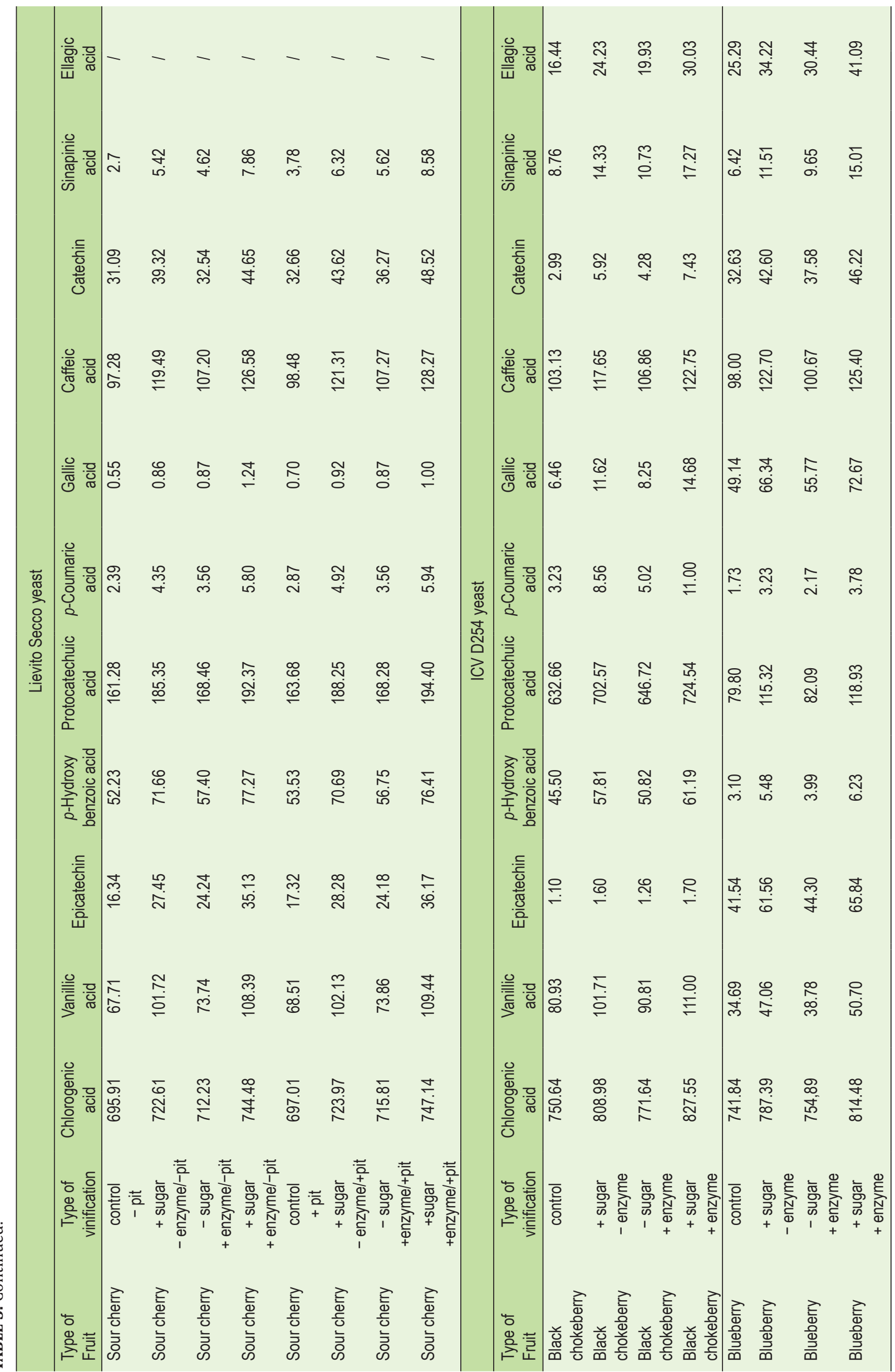




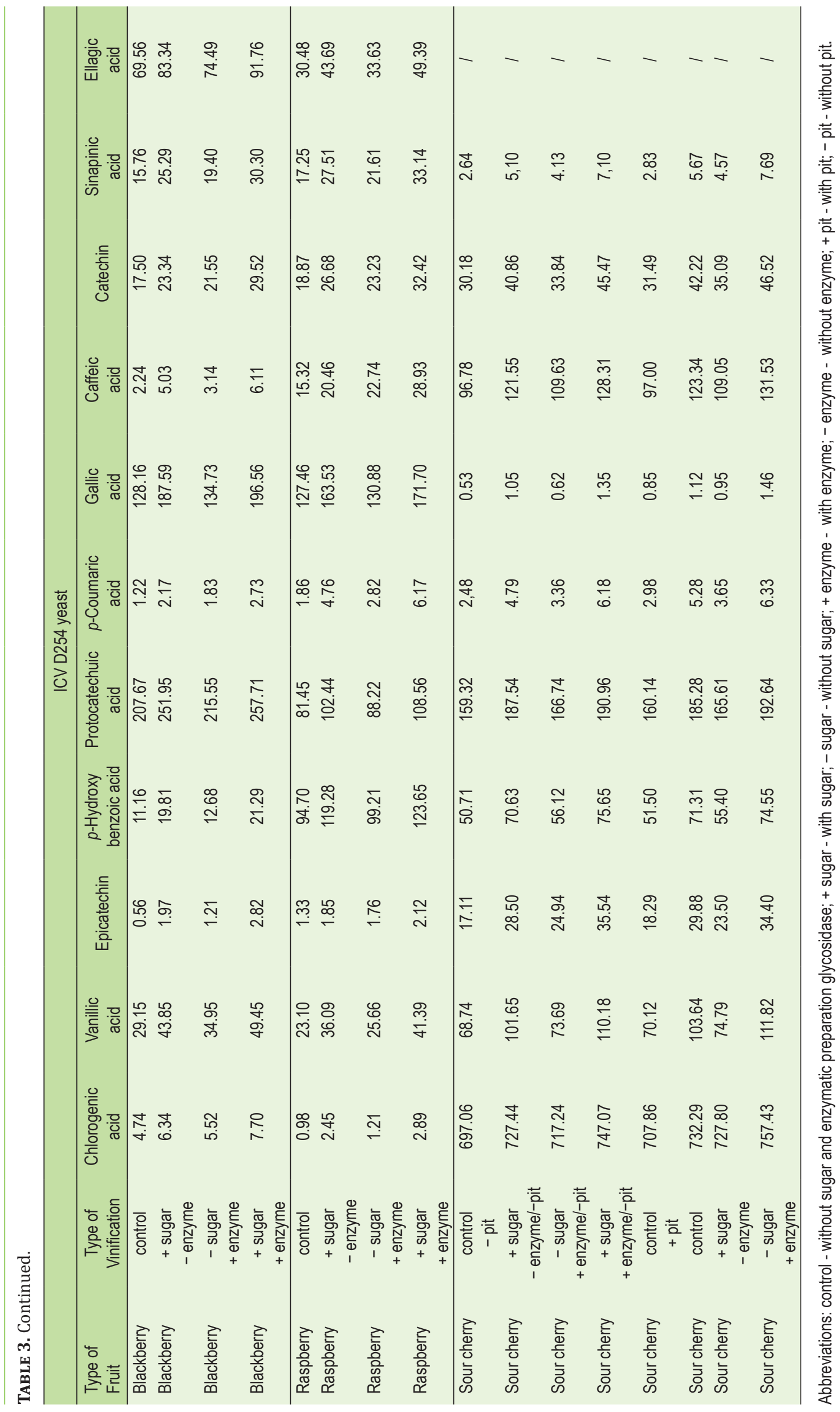


Sour cherry pomace was fermented in two ways (with and without pit), due to the impact of the pit on the wine phenolics content (Table 3). The samples fermented with Lievito Secco yeast were significantly different $(\mathrm{p}<0.05)$ in most of the cases except for those produced without sugar/ with EPG ( $p>0.05)$. However, the use of another yeast strain (ICV D254) lead to the fruit wine samples produced without sugar and EPG $(\mathrm{p}<0.05)$ as the only different one.

In order to estimate the influence of vinification procedure and fruit type on the content of phenolic compounds, two-way ANOVA analysis was applied. Indeed, vinification procedure did affect the content of phenolic compounds $(p<0.05)$ : the highest content was found in the samples prepared with sugar and EPG. Furthermore, the samples prepared with sugar/without EPG were richer in phenolics than those without sugar and with or without EPG. Finally, the samples prepared without sugar/with EPG contained more phenolic compounds than those made without sugar and EPG.

Similarly, fruit type was also found to affect the phenolics content in all cases $(\mathrm{p}<0.05)$.

The most abundant compound in cherry wine samples was chlorogenic acid (695.91-757.43 $\mathrm{g} \mathrm{mL}^{-1}$ ), while caffeic and $p$-coumaric acids were present in lower concentrations. These samples prepared with sugar, EPG, pit and ICV D254 yeast were enriched with caffeic acid $\left(131.53 \mu \mathrm{g} \mathrm{mL} \mathrm{L}^{-1}\right)$. On the other hand, $p$-coumaric acid content ranged from 2.39 to $6.33 \mu \mathrm{g} \mathrm{mL}^{-1}$. Chlorogenic and caffeic acid were higher in cherry wines than blackberry and raspberry ones $(\mathrm{p}<0.05)$. Additionally, the samples prepared with pit were richer in caffeic acid than blueberry ones $(\mathrm{p}<0.05)$. However, the same was not observed for cherry wines prepared without pit. On the other hand, $p$-coumaric acid was more abundant in these wines compared with blueberry, raspberry and blackberry ones $(\mathrm{p}<0.05)$. These findings go well in accordance with the previous ones claiming that chlorogenic acid was predominant in cherry wine (Czyzowska and Pogorzelski, 2002; Pantelić et al., 2014). Among hydroxybenzoic acid derivatives, protocatechuic acid (159.32-194.40 $\mathrm{g} \mathrm{mL}^{-1}$ ) was most abundant, as previously reported both for cherry wine and cherry fruit (Pantelić et al., 2014; Szwajgier et al., 2014). Actually, these wine samples were found to possess a higher content of protocatechuic acid than blueberry and raspberry ones $(\mathrm{p}<0.05)$. The same wines were richer in $p$-hydroxybenzoic acid than black chokeberry, blueberry and blackberry wines $(p<0.05)$. Compared with others, cherry wines stood out due to their high content of vanillic acid (111.82 $\left.\mu \mathrm{g} \mathrm{mL} \mathrm{L}^{-1}\right)(\mathrm{p}<0.05)$. Epicatechin and catechin contents were in a good agreement with the existing literature data (De Pascual-Teresa et al., 2000). Indeed, these two compounds were more abundant in cherry wines compared to the black chokeberry, blackberry and raspberry ones $(p<0.05)$. Ellagic acid was also identified, as reported thus far (Pantelić et al., 2014).

Hydroxycinnamic acid derivatives were the major ingredients of the blueberry wine samples (Table 3). More precisely, chlorogenic acid was the leading compound (730.88$814.48 \mu \mathrm{g} \mathrm{mL}^{-1}$ ). Actually, these samples were enriched with chlorogenic acid, compared to blackberry, raspberry and cherry wines $(p<0.05)$. Similar trend has been observed for blueberries and raspberries: the former fruit was enriched with the aforementioned acid (Kaihkonen et al., 2001).

Blueberry (prepared with Lievito Secco yeast) and black chokeberry (using the same yeast) wines were higher/lower in chlorogenic acid respectively than black chokeberry wines prepared with ICV D254 yeast $(\mathrm{p}<0.05)$. Furthermore, caffeic and $p$-coumaric acids were in the ranges 95.77-125.40 and 1.73-3.95 $\mu \mathrm{g} \mathrm{mL}^{-1}$, respectively. Indeed, these samples contained more caffeic acid than blackberry and raspberry ones $(\mathrm{p}<0.05)$. Both compounds have been known as the abundant ones in blueberries (Häkkinen et al., 1999; Zadernowski et al., 2005). The same wine samples were richer in gallic acid, compared to black chokeberry and cherry ones $(p<0.05)$. Protocatechuic acid was the most abundant hydroxybenzoic acid derivative, as previously reported (Zadernowski et al., 2005). Additionally, Häkkinen et al. (1999) confirmed the presence of $p$-hydroxybenzoic acid in blueberries. Hydroxycinnamic were more abundant than hydroxybenzoic acid derivatives, as described before (Zadernowski et al., 2005). Epicatechin and catechin were also identified, as expected (Liwei et al., 2003). Blueberry wines were enriched with epicatechin $\left(65.84 \mu \mathrm{g} \mathrm{mL} \mathrm{L}^{-1}\right)(\mathrm{p}<0.05)$. Such a finding is well supported by a Dutch study (Arts et al., 2000).

High content of chlorogenic, protocatechuic, $p$-coumaric and caffeic acids was found in the analysed fruit wine samples (Table 3). Indeed, chlorogenic $\left(827.55 \mu \mathrm{g} \mathrm{mL}^{-1}\right)$ and protocatechuic (724.54 $\left.\mu \mathrm{g} \mathrm{mL}^{-1}\right)$ acids were principal ingredients of black chokeberry wines. These samples actually represented richest source of protocatechuic acid $(\mathrm{p}<0.05)$. Further, chlorogenic acid was higher compared to blackberry, raspberry and cherry wine samples $(\mathrm{p}<0.05)$. These findings go well in accordance with the findings of a Finnish study on the berries (Kaihkonen et al., 2001) along with two other studies (Szwajgier et al., 2014; Grunovaite et al., 2016). By the way, $p$-hydroxybenzoic acid has been previously detected in chokeberry (Szwajgier et al., 2014). The measured content of caffeic and $p$-coumaric acids is in line with the existing literature data (Häkkinen et al., 1999). Actually, black chokeberry wines were found to be enriched with the aforementioned compounds $(\mathrm{p}<0.05)$. A Polish study reported a high content of $p$-coumaric acid in black chokeberry (Szwajgier et al., 2014). On the contrary, the content of catechin $(2.34 \mu \mathrm{g}$ $\mathrm{mL}^{-1}$ ) and ellagic acid (15.61 $\left.\mu \mathrm{g} \mathrm{mL}^{-1}\right)$ was poor in black chokeberry, while the findings for ellagic acid are in line with the previous ones (Häkkinen et al., 1999; Szwajgier et al., 2014).

Two major compounds of blackberry wines were gallic and protocatechuic acids (126.40-196.55 $\left.\mathrm{g} \mathrm{mL}^{-1}\right)$. Compared with others, blackberry wines were enriched with gallic acid $(p<0.05)$. Also, the same wines contained higher content of protocatechuic acid compared to blueberry, raspberry and cherry ones $(\mathrm{p}<0.05)$. However, this acid is more abundant in blackberry fruit (Zadernowski et al., 2005). Hydroxybenzoic acid derivatives such as $p$-hydroxybenzoic and vanillic acids were also identified (Table 3). Gallic acid was the major compound in the study focused on the Croatian blackberry wines (Amidžić Klarić et al., 2011). The obtained results are in a good agreement with the literature ones claiming that blackberries represent a rich source of gallic, protocatechuic and vanillic acids (Zadernowski et al., 2005). As in the study of Mosel and Herrmann (1974), protocatechuic acid was the most abundant compound. Among hydroxycinnamic acid derivatives, chlorogenic acid was found. It is worth mentioning that these samples contained the lowest concentrations of caffeic $\left(2.24 \mu \mathrm{g} \mathrm{mL}^{-1}\right)$ and $p$-coumaric $\left(1.22 \mu \mathrm{g} \mathrm{mL}^{-1}\right)$ acids. Such findings are in line with the previously reported ones (Amidžić Klarić et al., 2011). Zadernowski et al. (2005) found both caffeic and $p$-coumaric acids in blackberries. In some cases, $p$-coumaric acid was esterified (Mertz et al., 2007). Furthermore, these samples were enriched with sinapinic 
TABLE 4. FRAP, DPPH and Total Phenolic Contents (TPCs) of the selected fruit wine samples.

\begin{tabular}{|c|c|c|c|c|c|}
\hline \multirow[b]{2}{*}{ Type of fruit } & \multirow{2}{*}{$\begin{array}{c}\text { Type of } \\
\text { vinification }\end{array}$} & \multicolumn{2}{|c|}{ Lievito Secco yeast } & \multicolumn{2}{|c|}{ ICV D254 yeast } \\
\hline & & $\begin{array}{l}\text { FRAP corrected } \\
\left(\mathrm{mmol} \mathrm{L}^{-1} \mathrm{Fe}^{2+}\right)\end{array}$ & $\begin{array}{l}\text { Total Phenolic Content } \\
\text { (mg GAE L-1) }\end{array}$ & $\begin{array}{l}\text { FRAP corrected } \\
\left(\mathrm{mmol} \mathrm{L}^{-1} \mathrm{Fe}^{2+}\right)\end{array}$ & $\begin{array}{l}\text { Total Phenolic Content } \\
(\mathrm{mg} \mathrm{GAE} \mathrm{L-1})\end{array}$ \\
\hline Black chokeberry & control & 72.87 & 2351.00 & 72.38 & 2358.54 \\
\hline Black chokeberry & $\begin{array}{l}\text { + sugar } \\
\text { - enzyme }\end{array}$ & 83.70 & 2471.40 & 82.90 & 2482.45 \\
\hline Black chokeberry & $\begin{array}{l}\text { - sugar } \\
+ \text { enzyme }\end{array}$ & $75.26^{a, * *}$ & $2381.58^{a, * *}$ & $77.19^{a, \star *}$ & $2390.66^{a, \star *}$ \\
\hline Black chokeberry & $\begin{array}{l}\text { + sugar } \\
+ \text { enzyme }\end{array}$ & $86.35^{b, * *}$ & $2500.47^{b, * *}$ & $87.13^{b, * *}$ & $2520.40^{b, * *}$ \\
\hline Blueberry & control & 70.11 & 2259.33 & 70.43 & 2274.14 \\
\hline Blueberry & $\begin{array}{l}\text { + sugar } \\
\text { - enzyme }\end{array}$ & 79.61 & 2412.52 & 84.02 & 2419.44 \\
\hline Blueberry & $\begin{array}{l}\text { - sugar } \\
+ \text { enzyme }\end{array}$ & $75.69 a, * *$ & $2294.45^{a, *}$ & $75.18^{a, * *}$ & $2316.344^{a, *}$ \\
\hline Blueberry & $\begin{array}{l}\text { + sugar } \\
+ \text { enzyme }\end{array}$ & $87.78^{b, * *}$ & $2457.56^{b, *}$ & $87.36^{b, * *}$ & $2459.43^{b, *}$ \\
\hline Blackberry & control & 97.17 & 2262.33 & 100.25 & 2268.33 \\
\hline Blackberry & $\begin{array}{l}\text { + sugar } \\
\text { - enzyme }\end{array}$ & 109.11 & 2351.64 & 109.16 & 2358.70 \\
\hline Blackberry & $\begin{array}{l}\text { - sugar } \\
+ \text { enzyme }\end{array}$ & $101.52^{a, *}$ & $2297.71 \mathrm{a}^{*}$ * & $104.52^{a, * *}$ & $2303.56^{a, *}$ \\
\hline Blackberry & $\begin{array}{l}\text { + sugar } \\
+ \text { enzyme }\end{array}$ & $111.77^{b, *}$ & $2388.59 \mathrm{~b}, *$ & $115.23^{b, * *}$ & $2395.30^{b, *}$ \\
\hline Raspberry & control & 22.59 & 1448.44 & 23.42 & 1441.61 \\
\hline Raspberry & $\begin{array}{l}\text { + sugar } \\
\text { - enzyme }\end{array}$ & 29.83 & 1498.54 & 29.18 & 1496.50 \\
\hline Raspberry & $\begin{array}{l}\text { - sugar } \\
+ \text { enzyme }\end{array}$ & $25.44^{a, * *}$ & $1483.56 \mathrm{a}^{\mathrm{a}^{*}}$ & $26.44^{a, *}$ & $1471.27^{a, *}$ \\
\hline Raspberry & $\begin{array}{l}\text { + sugar } \\
+ \text { enzyme }\end{array}$ & $34.85^{b, * *}$ & $1544.37 \mathrm{~b}^{*}$ & $32.06^{b, *}$ & $1531.44 b_{,} *$ \\
\hline Sour cherry & $\begin{array}{l}\text { control } \\
\text { - pit }\end{array}$ & 50.33 & 1855.43 & 52.55 & 1860.45 \\
\hline Sour cherry & $\begin{array}{c}+ \text { sugar } \\
\text { - enzyme/-pit }\end{array}$ & 58.68 & 2141.58 & 60.30 & 2148.45 \\
\hline Sour cherry & $\begin{array}{c}\text { - sugar } \\
+ \text { enzyme/-pit }\end{array}$ & $55.43^{a, k}$ & $1953.29 \mathrm{a}, *$ & $54.48^{a, *}$ & $1959.42^{a, * *}$ \\
\hline Sour cherry & $\begin{array}{c}\text { + sugar } \\
+ \text { enzyme/-pit }\end{array}$ & $61.20 \mathrm{~b}, *$ & $2214.37 b, *$ & $62.21 \mathrm{~b}, *$ & $2219.65^{b, * *}$ \\
\hline Sour cherry & $\begin{array}{l}\text { control } \\
+ \text { pit }\end{array}$ & 52.12 & 1915.47 & 54.27 & 1921.48 \\
\hline Sour cherry & $\begin{array}{c}\text { + sugar } \\
\text { - enzyme/+pit }\end{array}$ & 61.47 & 2165.52 & 62.50 & 2170.36 \\
\hline Sour cherry & $\begin{array}{c}\text { - sugar } \\
\text { +enzyme/+pit }\end{array}$ & $56.26^{a, *}$ & $1989.40^{a, * *}$ & $59.76^{a, * *}$ & $1994.30^{a, * *}$ \\
\hline Sour cherry & $\begin{array}{c}\text { +sugar } \\
\text { +enzyme/+pit }\end{array}$ & $63.54^{\mathrm{b}, *}$ & $2276.52^{b, * *}$ & $64.89^{b, * *}$ & $2281.52^{b, * *}$ \\
\hline
\end{tabular}

a - significantly different from wine without sugar and enzymatic preparation glycosidase.

$b$ - Significantly different from wine with sugar and without enzymatic preparation glycosidase.

${ }^{*} p<0.05 ;{ }^{* *} p<0.01$.

acid, compared to black chokeberry, blueberry and cherry wines $(\mathrm{p}<0.05)$. In any way, both catechin and epicatechin were previously reported for blackberries (Arts et al., 2000; Liwei et al., 2003; Mertz et al., 2007). Within this study, ellagic acid was highest in blackberry wines $(\mathrm{p}<0.05)$. The same acid was highlighted in the study encompassing different blackberry cultivars (Siriwohaen and Wrolstad, 2004).

Hydroxybenzoic acid derivatives were the most abundant compounds in raspberry wine samples (Table 3). Gal- lic acid was the leading compound with the content varying from 127.46 to $171.70 \mu \mathrm{g} \mathrm{mL} \mathrm{L}^{-1}$.

Indeed, its content was higher in raspberry than in black chokeberry, blueberry and cherry wines $(\mathrm{p}<0.05)$. $p$-Hydroxybenzoic acid content also stood out $(p<0.05)$. The relevant literature data are in line with such findings (Mosel and Herrmann, 1974; Häkkinen et al., 1999). High content of protocatechuic acid $\left(108.56 \mu \mathrm{g} \mathrm{mL}^{-1}\right)$ was also observed, as previously reported (Mattila and Kumpulainen, 2002). The 
content of protocatechuic and gallic acids in the blackberry wines was higher than in the raspberry ones, as described before (Mosel and Herrmann, 1974). The lowest content of vanillic acid in the raspberry wines $\left(21.28 \mu \mathrm{g} \mathrm{mL}^{-1}\right)$ is in a good agreement with literature records (Mattila and Kumpulainen, 2002; Szwajgier et al., 2014). On the other hand, sinapinic acid was the most abundant (33.14 $\mathrm{g} \mathrm{mL}^{-1}$ ). Also, $p$-coumaric and caffeic acids were found, as previously reported (Häkkinen et al., 1999; Mattila and Kumpulainen, 2002). The lowest content of chlorogenic acid in raspberry wines $\left(0.98 \mu \mathrm{g} \mathrm{mL}^{-1}\right)$ is in line with the aforementioned Finnish study (Kaihkonen et al., 2001). Furthermore, ellagic acid was present in a considerable amount, higher than those of the black chokeberry and blueberry wines $(p<0.05)$. However, ellagic acid was lower in the raspberry wines than the blackberry ones, as previously reported by Milivojević et al. (2011). Finally, catechin and epicatechin contents were in accordance with the previous findings (Arts et al., 2000; Liwei et al., 2003).

Different experimental sets in vinification did show effect on TPC. The highest and lowest TPCs were found for the black chokeberry $\left(2,520 \mathrm{mg} \mathrm{GAE} \mathrm{L}^{-1}\right)$ and raspberry $(1,441 \mathrm{mg}$ GAE L ${ }^{-1}$ ) wine samples, respectively. According to two-way ANOVA analysis, the lowest TPC values were found for the samples without sugar and EPG and vice versa (Table 4). In addition to this, no interactions between the selected two factors were observed. Black chokeberry wines possessed higher TPC, compared to other fruit berries samples. The same trend was also observed by Zheng and Wang (2003). However, lower TPC values for blueberry wines exist in the available literature (Concepcion et al., 2003). Compared to the raspberry wines, higher TPC values were found for the blackberry ones, as described before (Moyer et al., 2002). Further, cherry and raspberry wines were found to possess lower TPC than the blueberry ones, as also reported by Vasantha Rupasinghe and Clegg (2007).

Quantitative differences throughout literature data may depend on the selection of cultivars, different climate conditions and/or sample preparation (Halvorsen et al., 2002). Dietary intake of phenolic acids is very important. Taking into account that berries represent a rich source of these compounds, they should have a significant role in the diet (Tomas-Barberan and Clifford, 2000; Mortaş and Şanlıer, 2017). Indeed, a Norwegian study supports such a claim (Halvorsen et al., 2002). Additionally, some fruitderived products such as juices also represent a good source of dietary antioxidants (Bhardwaj et al., 2014). For example, $p$-coumaric, caffeic and chlorogenic acids are known for their ability to block LDL oxidation in humans (Meyer et al., 1998). Berry fruits also positively affect cognitive function in humans, along with reducing the risk for neurodegenerative diseases (Lamport et al., 2014).

\section{Antioxidative potential}

The highest and lowest redox potentials (FRAP method) were observed for the blackberry $\left(115.23 \mathrm{mmol} \mathrm{L}^{-1} \mathrm{Fe}^{2+}\right)$ and raspberry (22.59 $\mathrm{mmol} \mathrm{L}^{-1} \mathrm{Fe}^{2+}$ ) wine samples, respectively (Table 4). As for anti-DPPH radical activity, the highest (1.11\%) and lowest $(5.25 \%)$ potentials were found for blackberry and raspberry wine samples. Both parameters most likely depend on the cumulative (synergistic) effect of various compounds present in fruit wines. Generally speaking, berry fruits possess a good antioxidant potential, but to a varying degree. Higher alcohol level improved the extraction of phenolic compounds leading to the enhanced antioxidant potential of the final product. EPG also contributed to more profound antioxidant potential. Twoway ANOVA analysis has pointed out that lowest FRAP values were found in fruit wine samples prepared without sugar and EPG and vice versa (Table 4). Statistically significant difference was noted for both factors (sugar and EPG) $(p<0.05)$. However, no interactions between these factors were observed. The obtained results are in a good agreement with the previous study focusing on berry fruits from Serbia that reported the highest/lowest FRAP and DPPH values for blackberry and raspberry, respectively (Mitic et al., 2014). On the other hand, the study on raspberries from Brazil supports the findings presented herein for anti-DPPH radical activity of the raspberry wine samples (Castilho Maro et al., 2013). Furthermore, the experimental data for redox potential of the blackberry wine samples are in line with the previous findings (Siriwohaen and Wrolstad, 2004). Compared with raspberry, Moyer et al. (2002) pointed out higher blackberry redox potential. Unlike cherries, black chokeberry and blueberry wines also possessed significant redox potentials. Vasantha Rupasinghe and Clegg (2007) also observed profound redox potential of blueberry. The same case is with blackberry, as reported thus far by Italian authors (Pellegrini et al., 2003). Finally, these authors reported about high redox potential of blueberry and raspberry, too.

\section{Principal Component Analysis (PCA)}

In order to make differentiation among experimental sets versus ten selected phenolics, grouping was carried out using the PCA statistical analysis with varimax rotation; the factor loadings below 0.3. were excluded. Kaiser-MeyerOlkin criterion was 0.6; the Bartlett's test of sphericity showed statistical significance $(\mathrm{p}<0.05)$. Two components were selected (93.2 variability, cumulatively), that was proven using the Cattell criterion. In brief, two groups are clearly distinguished: while the first one contains raspberry and blackberry, the second one includes cherry, blueberry and black chokeberry (Figure 2). As the most abundant compounds within the first group, gallic and sinapinic acids may be used for differentiation between the relevant fruit

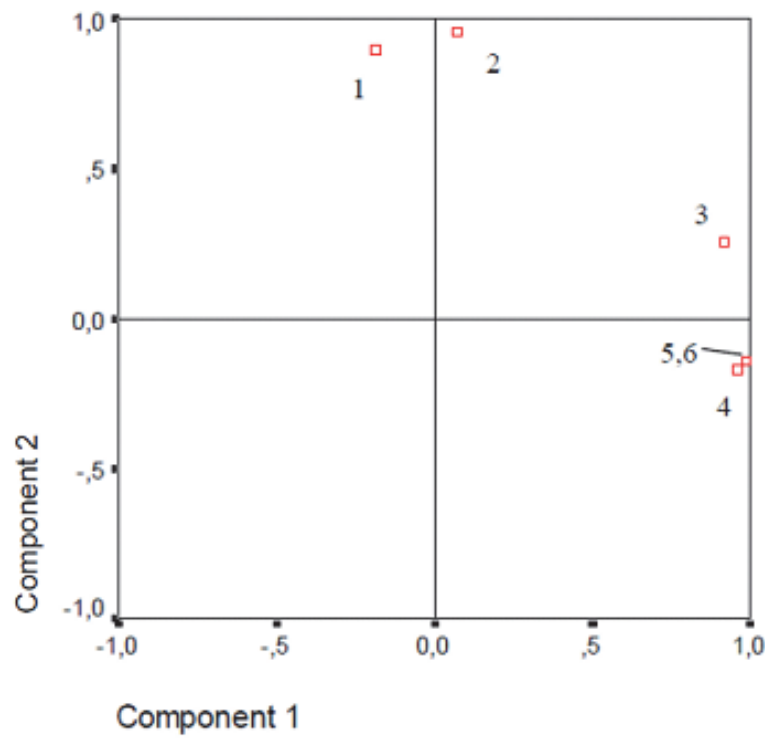

FigURE 2. Component plot in a rotated space.

1. raspberry wine; 2 . blackberry wine; 3 . black chokeberry wine; 4 . blueberry wine; 5 . sour cherry with pit; 6 . sour cherry without pit. 
wines. Similarly, chlorogenic and caffeic acids may be as a fingerprint in the case of the fruit wines encompassed by the second group.

\section{Conclusion}

Phenolic profile and antioxidant potential of the selected fruit wine samples were influenced by variable factors applied during vinification. In addition to this, the aforementioned wines can be classified according to their phenolic profiles. Berries in general and blackberries in particular do represent an important source of naturally occurring antioxidants that may show health-promoting properties. Therefore, very moderate consumption of berryfruit wines may be recommended as a part of healthy (wellbalanced) diet.

\section{Acknowledgments}

This work was supported by the Ministry of Education, Science and Technological Development of the Republic of Serbia (Research grants No's. III 46001 and 172053).

One of the authors (U.Č.) gratefully acknowledges to Jelena Milić, Georges Dagher and Marien Rouchon for their language editing assistance.

\section{References}

Amidžić Klarić, D., Klarić, I., and Mornar, A. (2011). Polyphenol content and antioxidant activity of commercial blackberry wines from Croatia: Application of multivariate analysis for geographic origin differentiation. J. Food Nutr. Res. 50, 199-209.

Arts, I.C.W., van de Putte, B., and Hollman, P.C.H. (2000). Catechin contents of foods commonly consumed in the Netherlands. 1. Fruits, vegetables, staple foods, and processed foods. J. Agr. Food Chem. 48, 1746-1751. https://doi.org/10.1021/jf000025h.

Atanacković, M., Petrović, A., Jović, S., Gojković-Bukarica, L., Bursać, M., and Cvejić, J. (2012). Influence of winemaking techniques on the resveratrol content, total phenolic content and antioxidant potential of red wines. Food Chem. 131, 513-518. https://doi.org/10.1016/j. foodchem.2011.09.015.

Benzie, I.F.F., and Strain, J.J. (1996). The ferric reducing ability of plasma (FRAP) as a measure of "antioxidant power": the FRAP assay. Anal. Biochem. 239, 70-76. https://doi.org/10.1006/ abio.1996.0292.

Bhardwaj, R.-L., Nandal, U., Pal, A., and Jain, S. (2014). Bioactive compounds and medicinal properties of fruit juices. Fruits $69,391-$ 412. https://doi.org/10.1051/fruits/2014027.

Blois, M.S. (1958). Antioxidant determinations by the use of a stabile free radical. Nature 181, 1199-1200. https://doi. org/10.1038/1811199a0.

Cao, G., Sofic, E., and Prior, L.R. (1997). Antioxidant and prooxidant behavior of flavonoids: structure-activity relationships. Free Radical Bio. Med. 22, 749-760. https://doi.org/10.1016/S08915849(96)00351-6.

Concepcion, S.M., Cao, G., Boxin, O.U., and Prior, R. (2003) Anthocyanin and proanthocyanidin content in selected white and red wines. Oxygen radical absorbance capacity comparison with nontraditional wines obtained from highbush blueberry. J. Agr. Food Chem. 51, 4889-4896. https://doi.org/10.1021/jf030081t.

Czyzowska, A., and Pogorzelski, E. (2002). Changes to polyphenols in the process of production of must and wines from blackcurrants and cherries. Part I. Total polyphenols and phenolic acids. Eur. Food Res. Technol. 214, 148-154. https://doi.org/10.1007/s00217-0010422-9.
De Pascual-Teresa, S., Santos-Buelga, C., and Rivas-Gonzalo, J.C. (2000). Quantitative analysis of flavan-3-ols in Spanish foodstuffs and beverages. J. Agr. Food Chem. 48, 5331-5337. https://doi. org/10.1021/jf000549h.

Đorđević, N.O., Novaković, M.M., Pejin, B., Mutić, J.J., Vajs, V.E., Pajović, S.B., and Tešević, V.V. (2017a). Comparative analytical study of the selected wine varieties grown in Montenegro. Nat. Prod. Res. 31, 1825-1830. https://doi.org/10.1080/14786419.2017.1289209.

Đorđević, N.O., Pejin, B., Novaković, M.M., Stanković, D.M., Mutić, J.J., Pajović, S.B., and Tešević, V.V. (2017b). Some chemical characteristics and antioxidant capacity of novel Merlot wine clones developed in Montenegro. Sci. Hortic. 225, 505-511. https://doi.org/10.1016/j. scienta.2017.07.045.

Dufresne, C.J., and Farnworth, E.R. (2001). A review of latest research findings on the health promotion properties of tea. J. Nutr. Biochem. 12, 404-421. https://doi.org/10.1016/S0955-2863(01)00155-3.

Eder, R., Wendelin, S., and Vrhovsek, U. (2000). Influence of viticultural and enological factors on the concentration of resveratrols in grapes and wine. Paper presented at $25^{\text {th }}$ Congres Mondial de la Vigne et du Vin (Paris, France), p. 79-86.

Ferreiro-González, M., Carrera, C., Ruiz-Rodríguez, A., Barbero, G.F., Ayuso, J., Palma, M., and Barroso, C.G. (2014). A new solid phase extraction for the determination of anthocyanins in grapes. Molecules 19, 21398-21410. https://doi.org/10.3390/molecules191221398.

Food and Agriculture Organisation of the United Nations (FAO) (2012). Top production of raspberries. http://faostat.fao.org/ site/339/default.aspx (accessed May 17, 2017).

German, J.B. (1997). In Flavonoids in Health and Disease, C.A. RiceEvans, and L. Packer, eds. (New York, USA: Marcel Dekker), p. 343358.

Grunovaite, L., Pukalskiene, M., Pukalskas, A., and Venskutonis, P.R. (2016). Fractionation of black chokeberry pomace into functional ingredients using high pressure extraction methods and evaluation of their antioxidant capacity and chemical composition. J. Funct. Foods 24, 85-96. https://doi.org/10.1016/j.jff.2016.03.018.

Häkkinen, S., Heinonen, M., Kärenlampi, S., Mykkänen, H., Ruuskanen, J., and Törrönen, R. (1999). Screening of selected flavonoids and phenolic acids in 19 berries. Food Res. Int. 32, 345-353. https://doi. org/10.1016/S0963-9969(99)00095-2.

Halvorsen, B.L., Holte, K., Myhrstad, M.C.W., Barikmo, I., Hvattum, E. Remberg, S.F., Wold, A.B., Haffner, K., Baugerød, H., Andersen, L.F., et al. (2002). A systematic screening of total antioxidants in dietary plants. J. Nutr. 132, 461-471.

Heinonen, I.M., Lehtonen, P.J., and Hopia, A.I. (1998). Antioxidant activity of berry and fruit wines and liquors, J. Agr. Food Chem. 46 , 25-31. https://doi.org/10.1021/jf970489o.

Johnson, M.H., Lucius, A., Meyer, T., and de Mejia, E.G. (2011). Cultivar evaluation and effect of fermentation on antioxidant capacity and in vitro inhibition of $\alpha$-amylase and $\alpha$-glucosidase by Highbush Blueberry (Vaccinium corombosum). J. Agr. Food Chem. 59, 89238930. https://doi.org/10.1021/jf201720z.

Joshi, V.K. (2009). Production of wines from non-grape fruit. Nat. Prod. Rad. 8, 313-469. Special Issue. (New Delhi: NISCARE)

Kaihkonen, M.P., Hopia, A.I., and Heinonen, M. (2001). Berry phenolics and their antioxidant activity. Agr. Food Chem. 49, 40764082. https://doi.org/10.1021/jf010152t.

Lamport, D.J., Dye, L., Wightman, J.D., and Lawton, C.L. (2014) Effects of berry polyphenols on cognitive function in humans Acta Hortic. 1017, 287-297. https://doi.org/10.17660/ ActaHortic.2014.1017.36. 
Liwei, G., Kelm, M.A., Hammerstone, J.F., Beecher, G., Holden, J., Haytowitz, D., and Prior, R.L. (2003). Screening of foods containing proanthocyanidins and their structural characterization using LCMS/MS and thiolytic degradation. J. Agr. Food Chem. 51, 7513-7521. https://doi.org/10.1021/jf034815d.

Maro, L.A.C., Pio, R., Guedes, M.N.S., de Abreu, C.M.P., and Curi, P.N (2013). Bioactive compounds, antioxidant activity and mineral composition of fruits of raspberry cultivars grown in subtropical areas in Brazil. Fruits 68, 209-217. https://doi.org/10.1051/ fruits/2013068.

Mattila, P., and Kumpulainen, J. (2002). Determination of free and total phenolic acids in plant-derived foods by HPLC with diodearray detection. J. Agr. Food Chem. 50, 3660-3667. https://doi. org/10.1021/jf020028p.

Mertz, C., Cheynier, V., Günata, Z., and Brat, P. (2007). Analysis of phenolic compounds in two blackberry species (Rubus glaucus and Rubus adenotrichus) by high-performance liquid chromatography with diode array detection and electrospray ion trap mass spectrometry. J. Agr. Food Chem. 55, 8616-8624. https://doi. org/10.1021/jf071475d

Meyer, A.S., Donovan, J.L., Pearson, D.A., Waterhouse, A.L., and Frankel, E.N. (1998). Fruit hydroxycinnamic acids inhibit human low-density lipoprotein oxidation in vitro. J. Agr. Food Chem. 46, 1783-1787. https://doi.org/10.1021/jf9708960.

Milivojević, J., Maksivović, V., Nikolić, M., Bogdanović, J., Maletić, R., and Milatović, D. (2011). Chemical and antioxidant properties of cultivated and wild Fragaria and Rubus berries. J. Food Qual. 34,1-9. https://doi.org/10.1111/j.1745-4557.2010.00360.x.

Mitic, V., Stankov Jovanovic, V., Dimitrijevic, M., Cvetkovic, J., Simonovic, S., and Nikolic Mandic, S. (2014). Chemometric analysis of antioxidant activity and anthocyanin content of selected wild and cultivated small fruit from Serbia. Fruits 69, 413-422. https://doi. org/10.1051/fruits/2014026.

Mortaș, H., and Şanlıer, N. (2017). Nutritional evaluation of commonly consumed berries: composition and health effects. Fruits 72, 5-23. https://doi.org/10.17660/th2017/72.1.1.

Mosel, H.D., and Herrmann, K. (1974). Phenolics of fruits. IV. The phenolics of blackberries and raspberries and their changes during development and ripeness of the fruits. Z. Lebensm. Untersuch. Forsch. 154, 324-327. https://doi.org/10.1007/BF01140817.

Moyer, R.A., Hummer, K.E., Finn, C.E., Frei, B., and Wrolstad, R.E. (2002). Anthocyanins, phenolics, and antioxidant capacity in diverse small fruits: Vaccinium, Rubus, and Ribes. J. Agr. Food Chem. 50, 519525. https://doi.org/10.1021/jf011062r

OIV. (2009). Compendium of international methods of wine and must analysis. (France: Organisation Internationale de la Vigne et du Vin).

Pantelić, M., Dabić, D., Matijašević, S., Davidović, S., Dojčinović, B., Milojković-Opsenica, D., Tešić, Ž., and Natić, M. (2014). Chemical characterization of fruit wine made from oblacinska sour cherry. Sci. World J., 9 pp. https://doi.org/10.1155/2014/454797.

Pellegrini, N., Serafini, M., Colombi, B., Rio, D.D., Salvatore, S.M., Bianchi, F., and Brighenti, F. (2003). Total antioxidant capacity of plant foods, beverages and oils consumed in Italy assessed by three different in vitro assays. J. Nutr. 133, 2812-2819.

Pinhero, R.G., and Paliyath, G. (2001). Antioxidant and calmodulin inhibitory activities of phenolic components in fruit wines and its biotechnological implications. Food Biotechnol. 15, 179-192. https://doi.org/10.1081/FBT-100107629.

Protić, D., Radunović, N., Spremović-Rađenović, S., Živanović, V., Heinle, H., Petrović, A., and Gojković-Bukarica, L. (2015). The role of potassium channels in the vasodilatation induced by resveratrol and naringenin in isolated human umbilical vein. Drug Dev. Res. 76, 17-23. https://doi.org/10.1002/ddr.21236.
Robards, K., Prenzler, P.D., Tucker, G., Swatsitang, P., and Glover, W. (1999). Phenolic compounds and their role in oxidative processes in fruits. Food Chem. 66, 401-436. https://doi.org/10.1016/S03088146(99)00093-X.

Siriwohaen, T., and Wrolstad, R.E. (2004). Polyphenolic composition of Marion and Evergreen blackberries. J. Food Sci. 69, 233-240. https://doi.org/10.1111/j.1365-2621.2004.tb06322.x.

Strik, B.C., Clark, J.R., Finn, C.E., and Bañados, M.P. (2007). Worldwide blackberry production. Horttechnology 17, 205-213. https://doi org/10.17660/ActaHortic.2008.777.31.

Stull, A.J., Cash, K.C., Johnson, W.D., Champagne, C.M., and Cefalu, W.T. (2010). Bioactives in blueberries improve insulin sensitivity in obese, insulin-resistant men and women. J. Nutr. 140, 1764-1768. https://doi.org/10.3945/jn.110.125336.

Swami, S.B., Thakor, N.J., and Divate, A.D. (2014). Fruit wine production: a review. J. Food Res. Technol. 2, 93-94.

Szwajgier, D., Halinowski, T., Helman, E., Tylus, K., and Tymcio, A. (2014). Influence of different heat treatments on the content of phenolic acids and their derivatives in selected fruits. Fruits 69, 167-178. https://doi.org/10.1051/fruits/2014004.

Tanner, H., and Brunner, H. (1979). Getränke-Analytik (Schwabisch Hall, Germany: Scheinfeld Verlag Heller Chemie- und Verwaltungsgesellschaft mbH), p.24.

Tomas-Barberan, F.A., and Clifford, M.N. (2000). Dietary hydroxybenzoic acid derivatives - nature, occurrence and dietary burden. J. Sci. Food Agr. 80, 1024-1032. https://doi.org/10.1002/ (SICI)1097-0010(20000515)80:7<1024::AID-JSFA567>3.0.CO;2-S.

Torres, A.M., Mau-Lastovicka, T., and Rezaaiyan, R. (1987). Total phenolics and high-performance liquid chromatography of phenolic acids of avocado. J. Agr. Food Chem. 35, 921-925. https://doi. org/10.1021/jf00078a018.

Vasantha Rupasinghe, H.P., and Clegg, S. (2007). Total antioxidant capacity, total phenolic content, mineral elements, and histamine concentrations in wines of different fruit sources. J. Food Compos. Anal. 20,133-137. https://doi.org/10.1016/j.jfca.2006.06.008.

Wang, S.Y. (2003). Antioxidant capacity of berry crops, culinary herbs and medicinal herbs. Acta Hortic. 620, 461-473. https://doi. org/10.17660/ActaHortic.2003.620.56.

Woraratphoka, J., Intarapichet, K.O., and Indrapichate, K. (2007). Phenolic compounds and antioxidative properties of selected wines from the northeast of Thailand. Food Chem. 104, 1485-1490. https://doi.org/10.1016/j.foodchem.2007.02.020.

Yoo, K.M., Al-Farsi, M., Lee, H., Yoon, H., and Lee, C.Y. (2010). Antiproliferative effects of cherry juice and wine in Chinese hamster lung fibroblast cells and their phenolic constituents and antioxidant activities. Food Chem. 123, 734-740. https://doi.org/10.1016/j. foodchem.2010.05.043.

Zadernowski, R., Naczk, M., and Nesterowicz, J. (2005). Phenolic acid profiles in some small berries. J. Agr. Food Chem. 53, 2118-2124. https://doi.org/10.1021/jf040411p.

Zheng, W., and Wang, S.Y. (2003). Oxygen radical absorbing capacity of phenolics in blueberries, cranberries, chokeberries, and lingonberries. J. Agr. Food Chem. 51, 502-509. https://doi. org/10.1021/jf020728u. 
Received: Jun. 26, 2017

Accepted: Nov. 28, 2017

Addresses of authors:

Uroš Čakar ${ }^{1, *}$, Aleksandar Petrović ${ }^{2}$, Milan Janković ${ }^{3}$,

Boris Pejin ${ }^{4, * *}$, Vlatka Vajs ${ }^{5}$, Mira Čakar ${ }^{1}$ and

Brižita Djordjević ${ }^{1}$

${ }^{1}$ Faculty of Pharmacy, University of Belgrade, Vojvode Stepe 450, 11000 Belgrade, Serbia

${ }^{2}$ Faculty of Agriculture, University of Belgrade, Nemanjina 6, 11080 Belgrade-Zemun, Serbia

${ }^{3}$ Faculty of Chemistry, University of Belgrade, Studentski trg 12-16, 11000 Belgrade, Serbia

${ }^{4}$ Institute for Multidisciplinary Research - IMSI, University of Belgrade, Kneza Višeslava 1, 11030 Belgrade, Serbia

${ }^{5}$ Institute of Chemistry, Technology and Metallurgy, University of Belgrade, Njegoševa 12, 11000 Belgrade, Serbia

Corresponding authors:

*E-mail:uroslion@gmail.com \& urosc@pharmacy.bg.ac.rs

** E-mail: brspjn@gmail.com \& borispejin@imsi.rs

Tel.: +381 (11) 3951 327; Fax: +381 (11) 3972840 